\title{
HYDROCHEMICAL CHARACTERISTICS AND WATER QUALITY ASSESSMENT IN ABU-ZAABAL AREA, EASTERN NILE DELTA, EGYPT
}

\author{
RAGAA EL-SHEIKH ${ }^{1}$, IBRAHIM HEGAZY ${ }^{1}$, EHAB ZAGHLOOL ${ }^{2}$, MOHAMED E. A. ALI², AYMAN A. GOUDA ${ }^{1 *}$
}

${ }^{1}$ Chemistry Department, Faculty of Science, Zagazig University, Zagazig, 44519, Egypt, ${ }^{2}$ Hydrogeochemistry Department, Desert Research Centre, Cairo, Egypt

Email: aymangouda77@gmail.com

Received: 17 Jun 2021, Revised and Accepted: 16 Aug 2021

\section{ABSTRACT}

Objective: The study presents simple tools for water resources quality classification based on its chemical compositions in Abu Zaabal area, eastern Nile Delta, Egypt and assess the water quality for different uses.

Methods: 31 water samples were collected from different water resources in the study area and analyzed for physicochemical parameters. Hydrochemical relations, contour maps and statistical methods were used to estimate the contamination indices and evaluate the water resources for different purposes.

Results: $83.3 \%$ of groundwater samples is fresh water and $16.7 \%$ are brackish water. $85.7 \%$ of surface water samples are fresh and $14.3 \%$ is saline. $92 \%$ of groundwater samples and $71.5 \%$ of surface water samples are very hard water. According to HPI values, $8 \%$ of the quaternary groundwater samples are good, $4 \%$ are poor, $4 \%$ are very poor and $84 \%$ of the samples are unsuitable. All groundwater samples and $71 \%$ of surface water samples are contaminated with respect to ammonia.

Conclusion: Higher concentrations of TDS and heavy metal may be due to the clay nature of the soil, the marine sediments in the aquifer matrix together with the dissolution and leaching of minerals from agricultural, anthropogenic and industrial activities. The groundwater in the polluted zones is considered unsuitable for human drinking.

Keywords: Water resources, Hydrochemistry, Water quality indices

(C) 2021 The Authors. Published by Innovare Academic Sciences Pvt Ltd. This is an open access article under the CC BY license (https://creativecommons.org/licenses/by/4.0// DOI: https://dx.doi.org/10.22159/ijap.2021v13i6.42562. Journal homepage: https://innovareacademics.in/journals/index.php/ijap

\section{INTRODUCTION}

Surface and Groundwater have an associated hydrological relationship affected by different factors related to geological; hydrological and climatic conditions where these factors control the circumstances of groundwater movement in shallow aquifers as well as the quantity of water can be gained or lost from the aquifer and river [1].

Due to industrial and agricultural activities, large amounts of untreated urban, industrial wastewater and rural household waste discharge into the Nile River, canals or agricultural drain, which become an easy dumping site for all types of wastes [2]. Ismailia Canal is the most distal downstream of the principal Nile River. And the water contains all the toxins that are discharged into the Nile. The Ismailia Canal has many pollution sources which potentially affect and deteriorate the canal's water quality [3]. Heavy metals are considered to be a serious pollution of aquatic ecosystems due to their environmental persistence and toxicity effects on living organisms [4]. In the aquatic environment, trace elements are partitioned between different environmental components (water, suspended solids, sediments and biota [5]. Water resources chemistry is due to long-term interaction between the water systems and the surrounding environment, which can indicate the water formation and migration [6, 7].

The objective of this present study is to highlight the chemical compositions of different water resources in Abu Zaabal area Eastern Nile Delta, Egypt. Assess the water quality for different uses.

The study area lies in the eastern portion of the River Nile delta in Qalyoubiya governorate, northeast Cairo city bounded by longitudes 31.320 and $31.440 \mathrm{E}$ and latitudes 30.240 and $30.320 \mathrm{~N}$, (fig. 1) occupies about $20 \mathrm{~km} 2$. The study area is bounded by Cairo ring road from the North, Belbis city from the south, Shebin El Qanater city from the west and Cairo-Belbeis desert road from the east.

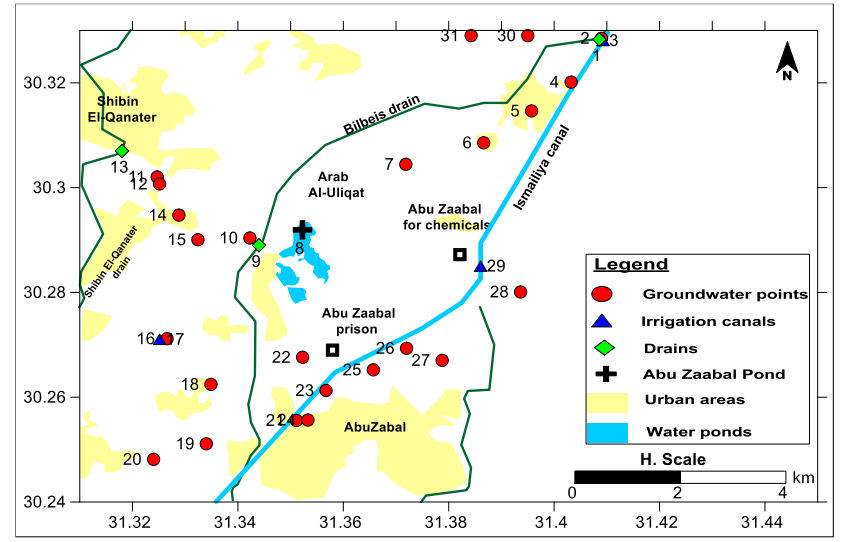

Fig. 1: The location map and sampling points of the area under investigation 
Abu Zaabal is considered as a plain area with an average elevation of $27 \mathrm{~m}$ above the mean sea level [8]. The area under investigation is characterized by cultivating lands surrounded by urban localities, The urban area is served by freshwater pipelines coming from a Mostorod water station is situated in the northern part of the study area as well as many shallow-private wells have been drilled for water extraction.

Geologically The Pleistocene and Holocene quaternary deposits cover most of the study area; the Basaltic rocks belonging to an Upper Oligocene age are exposed at Abu Zaabal area, while the Pliocene and Miocene sediments outcrops at the eastern part of Ismailia canal. The Holocene Nile silt and clay cover the majority of the study area with different thickness varies from 0 to $20 \mathrm{~m}$, the sand dune unites belongs to the Holocene age found in the eastern part of the study area.

The hydrological conditions and the groundwater aquifers of the eastern portion of the Nile delta were discussed by many authors [9-13].

The surface water infrastructure in the study area consists of a network of the surface water system (Ismailia canal, Belbies drain and Shebin El Qanater drain). The surface water systems are passing through Holocene deposits (Nile silt and clay deposits) and the Pleistocene sediments after the disappearance of the Holocene deposits. The contaminated liquids are directly discharged into canals, drain and on the land surface. The Pleistocene aquifer is influenced by the contaminated water infiltrates due to the small thickness of the clay cap.

The Quaternary aquifers are discriminated into the upper unit (Holocene aquitard) and the lower one (the Pleistocene aquifer) [11, 13 and 14]. The Pleistocene aquifer is overlain by the Holocene unit and underlain by the Pliocene clay in the majority of the area. Around Abu Zaabal Quarries, it is underlain by Miocene sediments or the Oligocene Basaltic sheet. The Holocene aquifer is composed of the Nile silt and clay, with thickness ranges between $0 \mathrm{~m}$ at the eastern portions of $20 \mathrm{~m}$ at the southwestern part of the study area. The Pleistocene aquifer consists of sand and gravel with clay lenses with thickness ranges between 0 to nearly $50 \mathrm{~m}$, while at the northwestern part of the investigated area, they may reach $200 \mathrm{~m}$. The groundwater movements in the Pleistocene aquifer are mainly due north and northwest reflected that Ismailia canal is the main recharging source as the surface water level in the canal is higher than the groundwater level. Besides, the recharges from irrigation canals and return flow after irrigation. Septic tanks and sewer systems are considered a local source of recharge. The main discharge of the Pleistocene aquifer takes place artificially through pumping wells used for irrigation and domestic uses.

\section{MATERIALS AND METHODS}

\section{Sampling procedures}

Thirty-one water samples were collected from different water resources (24 samples from groundwater wells and 7 samples represents surface water systems) in August 2019; Surface water samples were collected using an autosampler and polyvinyl chloride Van Dorn bottle

\section{Field measurements}

The location (longitudes and latitudes) of the water points was recorded using global positioning system (GPS) model etrex 10 (Germany).
Water samples were collected in a $1000 \mathrm{ml}$ clean polyethylene bottle which was used for major ions measurements, whereas a $50 \mathrm{ml}$ clean polyethylene bottles was acidified with concentrated $\mathrm{HNO}_{3}$ to $\mathrm{pH}<2$ for heavy metals detections. $\mathrm{E}$. $\mathrm{C}$ and $\mathrm{pH}$ were measured in situ using portable meters (AD 310 and 3510, Jenway, UK).

\section{Laboratory measurements}

The chemistry of water samples was detected in Hydrogeochemistry laboratories, Desert Research Center, Cairo, Egypt. The measuring of the major, minor constituents of the water samples (total dissolved solids (TDS), major ions as $\mathrm{Ca}^{2+}, \mathrm{Mg}^{2+}, \mathrm{Na}^{+}, \mathrm{K}^{+}, \mathrm{CO}_{3}{ }^{2-}, \mathrm{HCO}_{3}, \mathrm{SO}_{4}^{2-}, \mathrm{Cl}^{2}, \mathrm{NH}_{4}^{+}, \mathrm{NO}_{2}$, $\mathrm{NO}_{3}$ and $\mathrm{PO}_{4}{ }^{3-}$ ) were carried out according to the methods adopted by Bufflap SE and Allen HE (1995), Onken and Sunderman (1977), Fishman and Friedman (1985), Barer et al. (2000) and American Public Health Association (2005) [15-19] table 1.

Table 1: Methods adopted for water quality analysis

\begin{tabular}{ll}
\hline Quality parameter & Method used \\
\hline $\mathrm{PH}$ & Potentiometric $\left(1: 2.5 \mathrm{H}_{2} \mathrm{O}, \mathrm{v} / \mathrm{v}\right)$ \\
Electrical Conductivity EC & Conductometery $\left(1: 2.5 \mathrm{H}_{2} \mathrm{O}, \mathrm{v} / \mathrm{v}\right)$ \\
Calcium $\mathrm{Ca}^{2+}$ & EDTA $(0.05 \mathrm{~N})$ titrimetric \\
Magnesium $\mathrm{Mg}^{2+}$ & EDTA $(0.05 \mathrm{~N})$ titrimetric \\
Sodium $\mathrm{Na}^{+}$ & Flame photometric \\
Potassium $\mathrm{K}^{+}$ & Flame photometric \\
Chloride $\mathrm{Cl}^{-}$ & Titration using $0.05 \mathrm{~N} \mathrm{AgNO}_{3}$ \\
Carbonate $\mathrm{CO}_{3}{ }^{2-}$ & Titration (with $\left.0.01 \mathrm{~N} \mathrm{H}_{2} \mathrm{SO}_{4}\right)$ \\
Bicarbonate $\mathrm{HCO}_{3}$ & Titration (with $\left.0.01 \mathrm{~N} \mathrm{H}_{2} \mathrm{SO}_{4}\right)$ \\
Sulphate $\mathrm{SO}_{4}{ }^{2-}$ & Spectrophotometric \\
\hline
\end{tabular}

After physiochemical analysis, the accuracy of the analysis results (\% Balance error $(\% \mathrm{E})$ ) was checked. Generally speaking, the relative error should be within $\pm 5 \%$.

Heavy metals and trace components $(\mathrm{Al}, \mathrm{B}, \mathrm{Cd}, \mathrm{Co}, \mathrm{Cr}, \mathrm{Cu}, \mathrm{Fe}, \mathrm{Pb}, \mathrm{Mn}$, $\mathrm{Mo}, \mathrm{Ni}, \mathrm{Sr}, \mathrm{V}$ and $\mathrm{Zn}$ ) were detected by plasma optical emission mass spectrometer (ICP) (POEMSIII, thermo Jarrell elemental company USA), using $1000 \mathrm{mg} / \mathrm{l}$ (Merck) Stock solution for standard preparation. The water quality parameters were estimated to evaluate the water resources in the study area (tables 2, 3).

\section{RESULTS AND DISCUSSION}

\section{Physicochemical parameters of water resources}

The physical and chemical analyses of water samples in Abu Zaabal area are summarized in (tables 4, 5).

\section{Hydrogen ion concentration $(\mathrm{pH})$}

The $\mathrm{pH}$ value reflects the acidic or alkaline material present in the water. The decrease of $\mathrm{pH}$ less than 7 reflects an increase in hydrogen ion concentration. Where the increase in $\mathrm{pH}$ more than 7 is reflects an increase in the hydroxyl ion. In the study area, the $\mathrm{pH}$ values range from 7.8 to 8.6 and from 8.0 to 8.7 for the ground and surface water, respectively, which indicates that the water resources in the study area are generally alkaline in nature.

Table 2: Water quality parameter estimation methods from measured parameters

\begin{tabular}{|c|c|c|}
\hline Quality parameters & Formula adopted & Reference/source \\
\hline $\begin{array}{l}\text { Total dissolved solids } \\
\text { (TDS) }\end{array}$ & $\mathrm{TDS}=\left(\mathrm{Ca}^{2+}+\mathrm{Mg}^{2+}+\mathrm{Na}^{+}+\mathrm{K}^{+}+\mathrm{CO}_{3}+\left(\mathrm{HCO}_{3}-2\right)+\mathrm{SO}_{4}^{2-}+\mathrm{Cl}-\right)$ & [20] \\
\hline Total hardness (TH) & $\mathrm{TH}=(\mathrm{Ca}+\mathrm{Mg})^{\times} 50$ & [21] \\
\hline \multirow{7}{*}{$\begin{array}{l}\text { Heavy metal pollution } \\
\text { index (HPI) }\end{array}$} & $\mathrm{HPI}=\left(\sum \mathrm{W}_{\mathrm{i}} \times \mathrm{Q}_{\mathrm{i}}\right) / \sum \mathrm{W}_{\mathrm{i}}(1)$ & {$[22,23]$} \\
\hline & $\begin{array}{l}\text { Wi is the unit weightage of the heavy metal }(\mathrm{i}), \mathrm{n} \text { is the number of heavy metals, } \mathrm{Q} i \text { is the sub-index } \\
\text { of the heavy metal. }\end{array}$ & \\
\hline & $\mathrm{Wi}=\frac{\mathrm{K}}{\mathrm{Si}}(2) \mathrm{K}$ is the proportionality constant; $\mathrm{Si}$ is the standard permissible limit of the heavy metal. & \\
\hline & $\mathrm{K}=\frac{1}{\sum_{\mathrm{i}=1}^{\mathrm{n}} \mathrm{Si}} \sum_{\mathrm{Si}}^{\mathrm{n}} \frac{1}{\mathrm{Si}}=\frac{1}{\mathrm{~S} 1}+\frac{1}{\mathrm{~S} 2}+\cdots \frac{1}{\mathrm{Si}_{\mathrm{i}}}(3)$ & \\
\hline & Where, $S_{1}, S_{2}, S_{3}$, and Si represent standards for different heavy metals in the groundwater samples. & \\
\hline & $\mathrm{Q} \mathrm{i}=100 \mathrm{Xi} \frac{\mathrm{Vi}}{S i}(4) \mathrm{Vi}$ is the monitored value of the i parameter in $\mathrm{mg} / \mathrm{l}, \mathrm{HPI}$ is classified into five & \\
\hline & classes, excellent (0-25), good (26-50), poor (51-75), very poor (76-100) and unsuitable (100). & \\
\hline
\end{tabular}




\begin{tabular}{|c|c|c|}
\hline Quality parameters & Formula adopted & Reference/source \\
\hline $\begin{array}{l}\text { Nitrate pollution } \\
\text { index (NPI) }\end{array}$ & $\begin{array}{l}\text { NPI }=\frac{\text { Cs-HAV }}{\text { HAV }} \text { Where Cs: The analytical concentration of nitrate. HAV: The threshold value of } \\
\text { anthropogenic source (human affected value) taken as } 20 \mathrm{mg} / \text { l. The water quality according to NPI } \\
\text { values was classified into five types: clean (unpolluted) }(\mathrm{NPI}<0) \text {, light pollution }(0<\mathrm{NPI}<1) \text {, } \\
\text { moderate pollution }(1<\mathrm{NPI}<2) \text {, significant pollution }(2<\mathrm{NPI}<3) \text {, very significant pollution }(\mathrm{NPI}>3) \text {. }\end{array}$ & [24] \\
\hline $\begin{array}{l}\text { Drinking water } \\
\text { quality index (DWQI) }\end{array}$ & $\begin{array}{l}\text { The relative weight (Wi) is computed from the following equation: } \mathrm{Wi}=\text { wi } / \sum_{\mathrm{i}=1}^{\mathrm{n}} \text { wi where } \mathrm{Wi} \text { is the } \\
\text { relative weight wi is the weight of each parameter } \mathrm{n} \text { is the number of parameters qi= }(\mathrm{Ci} / \mathrm{Si}) \times 100 \\
\text { where qi is the quality rating } \mathrm{Ci} \text { is the concentration of each chemical parameter in each water } \\
\text { sample in milligrams per liter } \mathrm{Si} \text { is the Egyptian drinking water standard for each chemical } \\
\text { parameter in milligrams per liter according to the guidelines of the (Egyptian Higher Committee, } \\
2007 \text {; WHO, 2011). For computing the WQI, the SI is first determined for each chemical parameter, } \\
\text { which is then used to determine the WQI as per the following equation SIi =Wi } \times \text { qi WQI =SIi where } \\
\text { SIi is the sub-index of ith parameter qi is the rating based on the concentration of ith parameter } n \text { is } \\
\text { the number of parameters } \\
\text { The standard is the standard of the water quality parameter. The water samples were classified } \\
\text { according to WQI rate as excellent, good, poor, very poor and unfit for human consumption (table } 4) \text {. }\end{array}$ & [25] \\
\hline $\begin{array}{l}\text { Sodium Adsorption } \\
\text { Ratio (SAR) }\end{array}$ & $\mathrm{SAR}=\frac{\mathrm{Na}}{\sqrt{(\mathrm{Ca}+\mathrm{Mg}) / 2}}$ & {$[26]$} \\
\hline $\begin{array}{l}\text { Residual Sodium } \\
\text { Carbonate (RSC) }\end{array}$ & $\mathrm{RSC}=\left(\mathrm{CO}_{3}^{2-+} \mathrm{HCO}_{3}-\right)-\left(\mathrm{Ca}^{2+}+\mathrm{Mg}^{2+}\right)$ & [27] \\
\hline $\begin{array}{l}\text { Sodium percentage } \\
(\mathrm{Na} \%)\end{array}$ & $\% \mathrm{Na}=\left[\left(\mathrm{Na}^{+}+\mathrm{K}^{+}\right) /\left(\mathrm{Na}++\mathrm{K}^{+}+\mathrm{Ca}^{2+}+\mathrm{Mg}^{2+}\right)\right] \times 100$ & {$[28]$} \\
\hline $\begin{array}{l}\text { Magnesium ratio } \\
\text { (MAR) }\end{array}$ & $\mathrm{MAR}=\left[\mathrm{Mg}^{2+} /\left(\mathrm{Ca}^{2+}+\mathrm{Mg}^{2+}\right)\right] \times 100$ & [29] \\
\hline$\%$ Balance error $(\% \mathrm{E})$ & $\% \mathrm{E}=\left[\left(\sum\right.\right.$ cation-anion $) /\left(\sum\right.$ cation + anion $\left.)\right] \times 100$ & {$[20]$} \\
\hline
\end{tabular}

Table 3: Water quality parameters, their standard values, their ideal values and the assigned weighting factors

\begin{tabular}{|c|c|c|c|}
\hline Parameter & Standard value (Si) & Weight (wi) & Realative weight Wi \\
\hline TDS & 1000 & 5 & 0.161 \\
\hline $\mathrm{Ca} 2+$ & 200 & 3 & 0.097 \\
\hline $\mathrm{Mg} 2+$ & 150 & 3 & 0.097 \\
\hline $\mathrm{Na}+$ & 200 & 4 & 0.129 \\
\hline $\mathrm{HCO}-$ & $500^{*}$ & 1 & 0.032 \\
\hline SO42- & 250 & 5 & 0.161 \\
\hline Cl- & 250 & 5 & 0.161 \\
\hline NO3 & 45 & 5 & 0.161 \\
\hline The values a & an standards (2007) a & & 0.14 \\
\hline
\end{tabular}

\section{Total dissolved solids (TDS)}

The water salinity of groundwater ranges of $243 \mathrm{mg} / \mathrm{l}$ to $3390 \mathrm{mg} / \mathrm{l}$ and in surface water of $240 \mathrm{mg} / \mathrm{l}$ to $5600 \mathrm{mg} / \mathrm{l}$, as shown in (fig. 2). $83.3 \%$ of groundwater samples are fresh water and $16.7 \%$ are brackish water. $85.7 \%$ from surface water samples are fresh and $14.3 \%$ is saline. Higher concentrations of TDS may be credited to the impact of evaporation and the marine sediments in the aquifer matrix together with the dissolution and leaching of minerals from agricultural, anthropogenic and industrial activities [32,33].

\section{Total hardness}

The total hardness (TH) is caused primarily by the presence of cations such as calcium and magnesium and anions such as carbonate, bicarbonate, chloride and sulfate in water. The total hardness values of groundwater samples range from $150 \mathrm{mg} / \mathrm{l}$ to $1300 \mathrm{mg} / \mathrm{l}$ reflected that $8 \%$ of these samples are hard and $92 \%$ are very hard water. The total hardness values in surface water range from $140 \mathrm{mg} / \mathrm{l}$ to $1480 \mathrm{mg} / \mathrm{l}$ reflected that $28.5 \%$ of samples are hard and $71.5 \%$ are very hard.

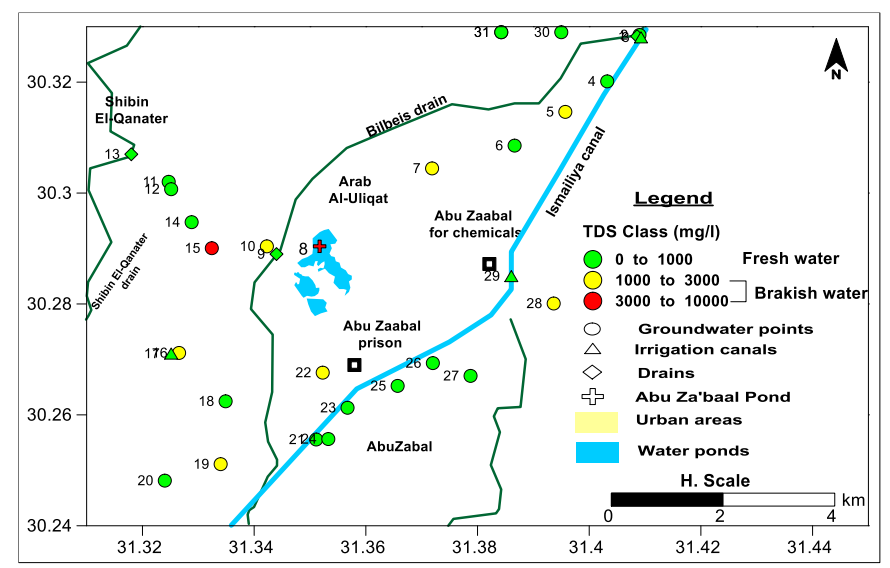

Fig. 2: TDS classification map for the quaternary groundwater in the study area 


\section{Soluble anions}

Bicarbonate ion $\left(\mathrm{HCO}_{3}^{-}\right)$source is from the dissolution of carbonate rocks (dolomite, limestone, magnesites etc.). $\mathrm{HCO}_{3}$ is mainly formed due to the action of $\mathrm{CO}_{2}$ from the atmosphere and that released from organic decomposition [34, 35]. Bicarbonate concentration in groundwater of the Quaternary (Pleistocene) aquifer varies from $138 \mathrm{mg} / \mathrm{l}$ to $520 \mathrm{mg} / \mathrm{l}$ and in surface water from $134 \mathrm{mg} / \mathrm{l}$ to 420 $\mathrm{mg} / \mathrm{l}$. The bicarbonate distribution in groundwater indicates that high content and the presence of local variations advocates the existence of local pollution sources. The distribution of bicarbonate salts increased from west to east. This direction may be due to the recharge of the quaternary aquifer from the Ismailia canal (fig. 3. a).

Sulfate ion $\left(\mathrm{SO}_{4}{ }^{2-}\right)$ is naturally formed due to rock weathering, input from volcanoes and biochemical process [36]. The oxidation and decomposition of substances containing sulfur (fossil fuels and dissolution of sulfur-bearing minerals such as gypsum and pyrite) and anthropogenic activities are other sources of $\mathrm{SO}_{4}$ ions [35]. The sulfate content in groundwater of the Quaternary aquifer varies from 23.1 $\mathrm{mg} / \mathrm{l}$ to $780 \mathrm{mg} / \mathrm{l}$ and from $28.9 \mathrm{mg} / \mathrm{l}$ to $1080 \mathrm{mg} / \mathrm{l}$ in surface water. The groundwater distribution of sulfate indicates the presence of local zones of high concentrations at Abu Zaabal, reflecting that the effect of the saline pond from the west and the influence of the sulfate fertilizers in the new reclaimed land in the east (fig. 3. b).

The $\mathrm{Cl}$-ion form in nature is usually of chlorine salts $\left(\mathrm{CaCl}_{2}, \mathrm{MgCl}_{2}\right.$ and $\mathrm{NaCl}$ ). The main source is due to the leaching and dissolution of sedimentary rocks; common evaporates minerals and saline deposits. Industrial, municipal wastes and irrigated agricultural activities are other main sources of chloride salts [37]. The chloride content varies from $32 \mathrm{mg} / \mathrm{l}$ to $970 \mathrm{mg} / \mathrm{l}$ in the quaternary groundwater samples and from $35 \mathrm{mg} / \mathrm{l}$ to $1750 \mathrm{mg} / \mathrm{l}$ in surface water. The chloride content distribution in groundwater shows the presence of local zones of high concentrations at Abu Zaabal. The local variations in the chloride concentrations are attributed to local recharge from the saline ponds in the study area; this also confirms the existence of local pollution sources (fig. 3. c).

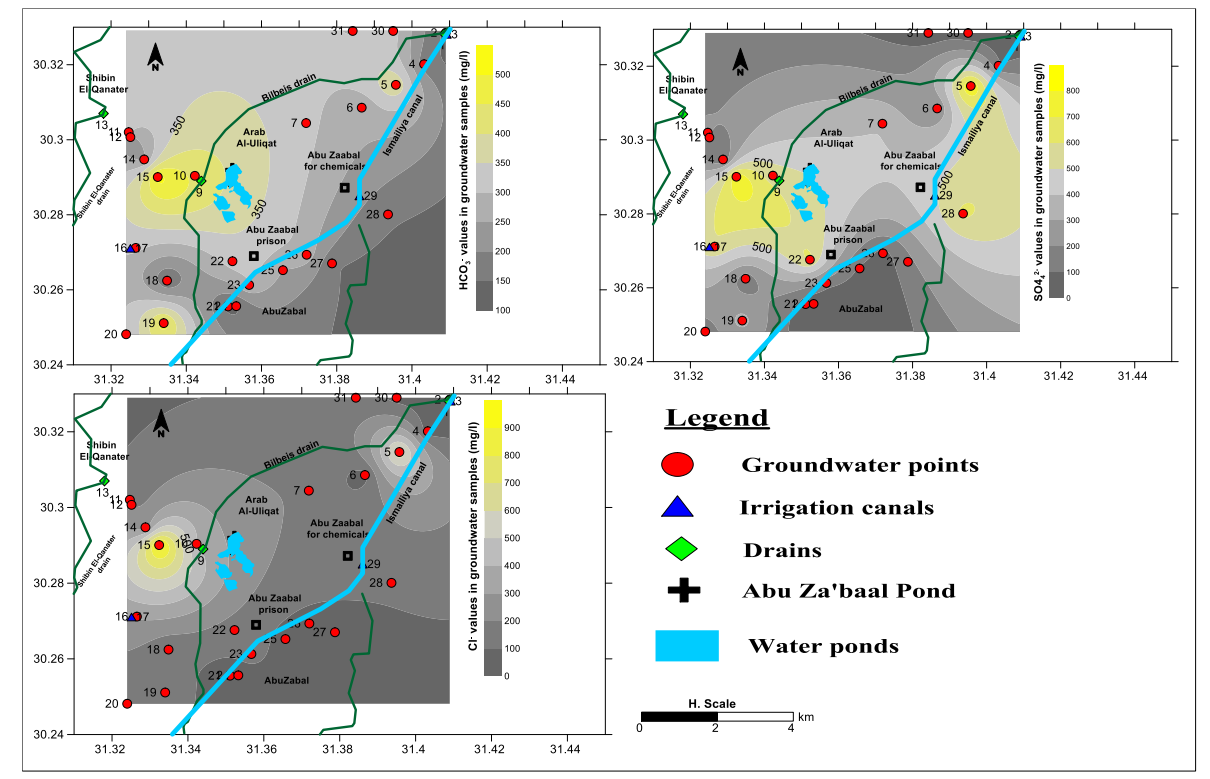

Fig. 3: Spatial distribution map of anions concentrations in the quaternary groundwater in the study area

\section{Soluble cations}

Calcium plays an important role in the health of water bodies which reduces the toxicity of $s$ chemical compounds in natural water [38]. The removal of $\mathrm{Ca}^{2+}$ ion from the water resources is due to an ionexchange or calcite $\left(\mathrm{CaCO}_{3}{ }^{2-}\right)$ precipitation. Calcite precipitation occurs when $\mathrm{CO}_{2}$ content is low, causing the chemical reaction process in the reverse direction [35]. The calcium content in groundwater of the Quaternary aquifer varies from $32.8 \mathrm{mg} / \mathrm{l}$ to 392 $\mathrm{mg} / \mathrm{l}$ and from $32.8 \mathrm{mg} / \mathrm{l}$ to $384 \mathrm{mg} / \mathrm{l}$ in the surface water samples. The calcium distribution in groundwater confirms the presence of local zones of high concentrations that occurred at Abu Zaabal (fig. 4 . a). Hardness of water is attributed to the presence of calcium and magnesium ions; the water in the study area varied from hard to very hard.

A magnesium source water resources is due to chemical weathering and dissolution of dolomite, marls and other rocks [39]. Magnesium content in the Quaternary aquifer samples varies from $13.92 \mathrm{mg} / \mathrm{l}$ to $114 \mathrm{mg} / \mathrm{l}$ and from $11.5 \mathrm{mg} / \mathrm{l}$ to $124.8 \mathrm{mg} / \mathrm{l}$ in surface water. The magnesium distribution in groundwater shows the presence of local zones of high concentrations, but the magnesium contents are still below the excessive limits for drinking (fig. 4. b).

A sodium source in the water resources is due to weathering of $\mathrm{Na}$ bearing minerals/rocks (halite, feldspar and montmorillonite), cation-exchange process (displacement from absorbing complex of rocks and soils by $\mathrm{Ca}$ and $\mathrm{Mg}$ ), and anthropogenic activities (pollution from industrial effluent, domestic sewage, and agricultural activities). Sodium content in groundwater of the Quaternary (Pleistocene) aquifer varies from $18 \mathrm{mg} / \mathrm{l}$ to $442.9 \mathrm{mg} / \mathrm{l}$ and from $20 \mathrm{mg} / \mathrm{l}$ to $1265 \mathrm{mg} / \mathrm{l}$ in surface water. The distribution of sodium ions in the study area reflects local variations may be attributed to local recharge from the saline ponds in the study area. The groundwater in the polluted zones is considered unsuitable for drinking (fig. 4. c). Potassium is slightly less common than sodium in igneous rocks, but more abundant in all sedimentary rocks. In igneous rocks, potassium is present as feldspars (orthoclase and microcline $\left(\mathrm{KAlSi}_{3} \mathrm{O}_{3}\right)$ ), wherein sediments it is present in clay minerals. Potassium is slightly less common than sodium in igneous rocks, but more abundant in all sedimentary rocks. In igneous rocks, potassium is present as feldspres (orthoclase and microcline $\left(\mathrm{KAlSi}_{3} \mathrm{O}_{3}\right)$ ), wherein sediments it is present in clay minerals. The concentration of potassium in natural water is generally less than $10 \mathrm{mg} / \mathrm{l}$ as much as $100 \mathrm{mg} / \mathrm{l}$ in hot springs and about $25000 \mathrm{mg} / \mathrm{l}$ in brines.

\section{Minor, trace and heavy metals}

Nitrate concentrations in the groundwater samples ranges between $12 \mathrm{mg} / \mathrm{l}$ to $42 \mathrm{mg} / \mathrm{l}$ and from $8 \mathrm{mg} / \mathrm{l}$ to $75 \mathrm{mg} / \mathrm{l}$ in the surface water samples. Nitrite concentration in the groundwater samples ranged between $0.05 \mathrm{mg} / \mathrm{l}$ to $0.51 \mathrm{mg} / \mathrm{l}$ and from $0.01 \mathrm{mg} / \mathrm{l}$ to $0.61 \mathrm{mg} / \mathrm{l}$ in the surface water samples. Ammonia concentration in the groundwater samples ranges between $0.5 \mathrm{mg} / \mathrm{l}$ to $3.7 \mathrm{mg} / \mathrm{l}$ and from 
$0.1 \mathrm{mg} / \mathrm{l}$ to $8 \mathrm{mg} / \mathrm{l}$ in the surface water samples. From the previous data, the groundwater samples are contaminated with ammonia. This shows that groundwater samples is mixed with sewage and the presence of Escherichia coli bacteria from bacteriological analysis of some groundwater samples proved that

Iron content, $83.3 \%$ of groundwater samples in the Pleistocene aquifers of Abu Zaabal area are unsuitable for human drinking, while the rest of the samples (16.7\%) are suitable for drinking. On the other hand, $71.4 \%$ of surface water samples are unsuitable for human drinking, while the rest of the samples $(28.6 \%)$ are suitable for drinking. Iron values of groundwater ranges from $0.004 \mathrm{mg} / \mathrm{l}$ to
$5.39 \mathrm{mg} / \mathrm{l}$ and in surface water from $0.03 \mathrm{mg} / \mathrm{l}$ to $6.96 \mathrm{mg} / \mathrm{l}$. This is due to the clay nature of the soil.

Manganese content (33.3\%) of the groundwater samples and 28.6\% of surface water samples are unsuitable for drinking. Lead content $(12.5 \%)$ of the groundwater samples is unsuitable for drinking. Cadmium content, (83.3\%) of the groundwater samples and $71.4 \%$ of surface water samples are unsuitable for drinking. Aluminum content $(8.3 \%)$ of the groundwater samples and $71.4 \%$ of surface water samples are unsuitable for drinking. Nickel content $(12.5 \%)$ of the groundwater samples and $42.8 \%$ of surface water samples are unsuitable for drinking.

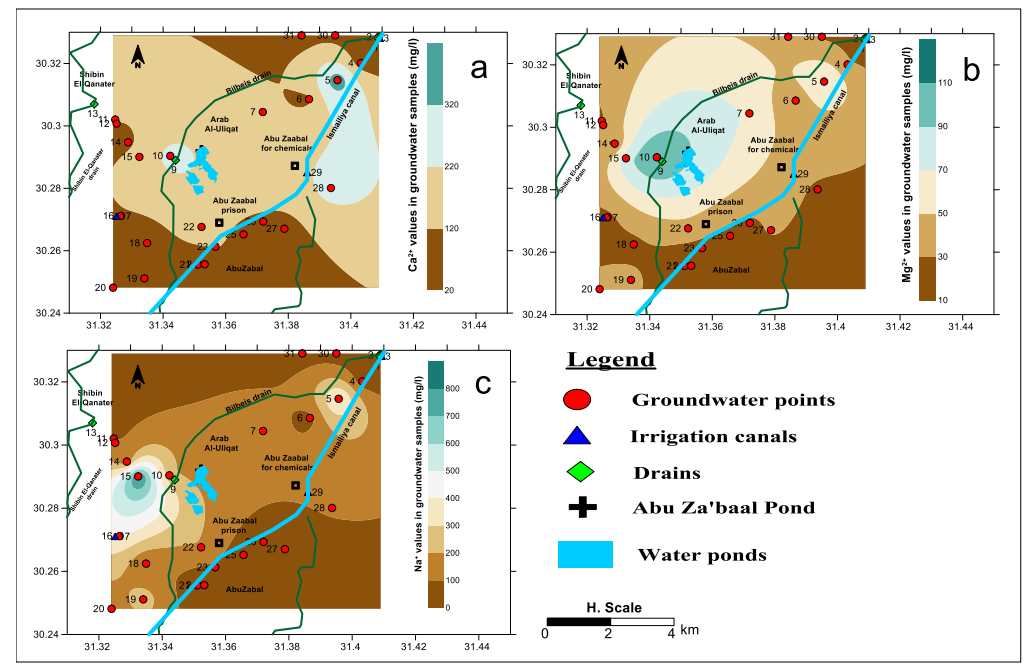

Fig. 4: Spatial distribution map of cations concentrations in the quaternary groundwater in the study area

Table 4: Major and minor element concentrations of water samples in Abu Zaabal area

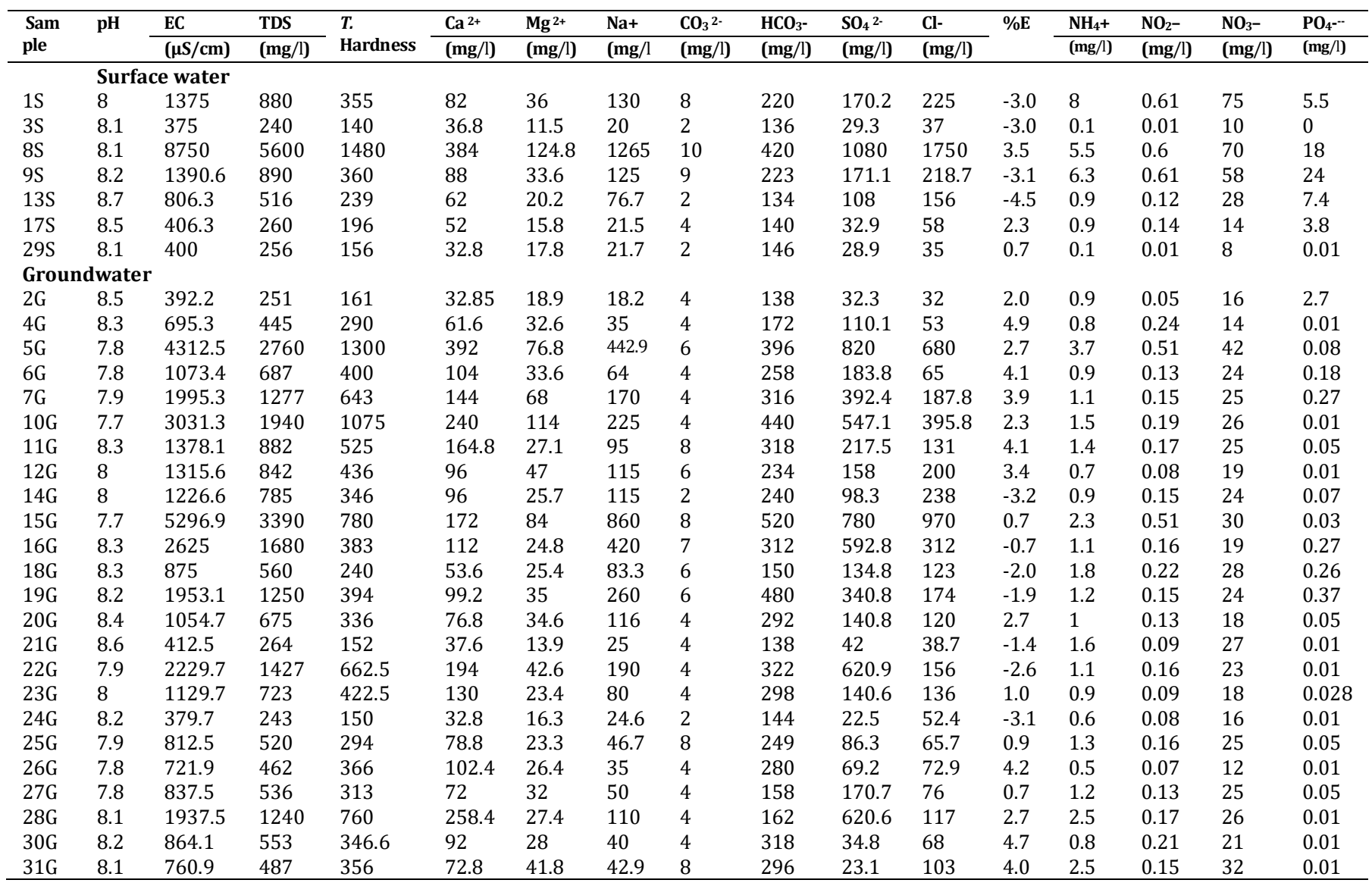


Table 5: Trace and heavy metal concentrations of water samples in Abu Zaabal area in $\mathbf{m g} / \mathrm{l}$ unit

\begin{tabular}{|c|c|c|c|c|c|c|c|c|c|c|c|}
\hline \multirow[t]{2}{*}{ Sample } & Al & Co & $\mathrm{Cu}$ & Cd & $\mathbf{F e}$ & $\mathbf{P b}$ & $\mathbf{S r}$ & Mn & Mo & $\mathrm{Ni}$ & $\mathbf{B a}$ \\
\hline & \multicolumn{11}{|c|}{ Surface water } \\
\hline $1 \mathrm{~S}$ & 1.29 & 0.035 & 0.050 & 0.042 & 2.368 & $<0.008$ & 1.556 & 0.192 & 0.090 & 0.082 & 0.092 \\
\hline $3 S$ & 1.26 & 0.097 & $<0.006$ & $<0.0006$ & 0.030 & $<0.008$ & 0.400 & 0.090 & 0.107 & $<0.002$ & 0.071 \\
\hline $8 \mathrm{~S}$ & 14.29 & $<0.001$ & 0.065 & 0.047 & 6.960 & $<0.008$ & 12.290 & 0.819 & 0.036 & $<0.002$ & 0.097 \\
\hline $9 \mathrm{~S}$ & 1.04 & $<0.001$ & 0.078 & 0.027 & 2.836 & $<0.008$ & 1.578 & 0.158 & $<0.001$ & 0.072 & 0.098 \\
\hline $13 S$ & 2.01 & 0.007 & 0.039 & 0.028 & 1.430 & $<0.008$ & 0.584 & 0.118 & $<0.001$ & $<0.002$ & 0.067 \\
\hline $17 \mathrm{~S}$ & 0.01 & $<0.001$ & $<0.006$ & 0.015 & 1.827 & $<0.008$ & 1.444 & 0.661 & 0.075 & 0.028 & 0.041 \\
\hline $29 S$ & 0.15 & 0.010 & 0.034 & $<0.0006$ & 0.061 & $<0.008$ & 0.599 & $<0.002$ & 0.025 & $<0.002$ & 0.082 \\
\hline \multicolumn{12}{|c|}{ Groundwater } \\
\hline $2 \mathrm{G}$ & 0.10 & 0.023 & $<0.006$ & 0.028 & 0.695 & $<0.008$ & 0.348 & 0.035 & 0.043 & $<0.002$ & 0.0720 \\
\hline $4 \mathrm{G}$ & $<0.01$ & $<0.001$ & $<0.006$ & 0.029 & 0.495 & $<0.008$ & 0.645 & 0.192 & 0.027 & $<0.002$ & 0.070 \\
\hline $5 G$ & 0.08 & 0.008 & 0.006 & 0.050 & 0.463 & $<0.008$ & 3.808 & 0.902 & 0.051 & 0.020 & 0.070 \\
\hline $6 \mathrm{G}$ & 0.16 & 0.010 & 0.022 & 0.026 & 0.518 & 0.052 & 1.909 & 0.421 & 0.003 & 0.011 & 0.069 \\
\hline $7 \mathrm{G}$ & 0.12 & $<0.001$ & 0.012 & 0.009 & 0.445 & $<0.008$ & 2.954 & 0.016 & 0.065 & $<0.002$ & 0.060 \\
\hline $10 \mathrm{G}$ & 0.06 & 0.003 & 0.020 & 0.027 & 4.730 & 0.019 & 2.282 & 0.848 & $<0.001$ & 0.028 & 0.135 \\
\hline $11 \mathrm{G}$ & 0.00 & 0.000 & $<0.006$ & 0.024 & 3.980 & $<0.008$ & 1.281 & 0.509 & 0.018 & 0.014 & 0.131 \\
\hline $12 \mathrm{G}$ & 0.11 & $<0.001$ & $<0.006$ & 0.025 & 0.500 & $<0.008$ & 1.433 & 0.200 & $<0.001$ & 0.010 & 0.111 \\
\hline $14 \mathrm{G}$ & 0.0738 & 0.033 & 0.021 & 0.009 & 0.304 & $<0.008$ & 0.857 & 0.206 & 0.112 & $<0.002$ & 0.030 \\
\hline $15 G$ & $<0.01$ & 0.039 & $<0.006$ & 0.045 & 0.159 & 0.156 & 4.524 & 0.843 & 0.064 & 0.035 & 0.0469 \\
\hline $16 \mathrm{G}$ & 0.03 & 0.043 & 0.019 & 0.003 & 5.390 & $<0.008$ & 4.795 & 0.921 & 0.051 & $<0.002$ & 0.049 \\
\hline $18 \mathrm{G}$ & 0.33 & 0.072 & $<0.006$ & $<0.0006$ & 2.220 & $<0.008$ & 0.332 & 0.041 & $<0.001$ & $<0.002$ & 0.034 \\
\hline $19 G$ & $<0.01$ & 0.021 & 0.014 & 0.011 & 2.190 & $<0.008$ & 1.394 & 0.115 & 0.003 & 0.013 & 0.138 \\
\hline $20 G$ & 0.16 & $<0.001$ & 0.001 & 0.018 & 0.940 & $<0.008$ & 0.463 & 0.044 & 0.061 & $<0.002$ & 0.067 \\
\hline $21 \mathrm{G}$ & 0.05 & 0.001 & 0.057 & 0.056 & 0.218 & $<0.008$ & 7.011 & 0.221 & $<0.001$ & $<0.002$ & 0.144 \\
\hline $22 \mathrm{G}$ & $<0.01$ & $<0.001$ & $<0.006$ & 0.038 & 1.277 & $<0.008$ & 1.564 & 0.139 & 0.000 & $<0.002$ & 0.497 \\
\hline $23 G$ & 0.04 & 0.062 & $<0.006$ & 0.025 & 0.777 & $<0.008$ & 0.337 & 0.102 & $<0.001$ & $<0.002$ & 0.073 \\
\hline $24 \mathrm{G}$ & $<0.01$ & 0.049 & 0.024 & 0.011 & 0.028 & $<0.008$ & 1.315 & 0.008 & $<0.001$ & $<0.002$ & 0.089 \\
\hline $25 G$ & $<0.01$ & 0.021 & 0.032 & 0.037 & 0.004 & $<0.008$ & 0.728 & 0.088 & $<0.001$ & 0.015 & 0.143 \\
\hline $26 G$ & 0.18 & 0.047 & 0.085 & 0.071 & 0.400 & $<0.008$ & 1.112 & 0.881 & 0.159 & $<0.002$ & 0.307 \\
\hline $27 \mathrm{G}$ & $<0.01$ & $<0.001$ & 0.001 & $<0.0006$ & 2.670 & $<0.008$ & 4.574 & 0.061 & 0.067 & 0.054 & 0.083 \\
\hline $28 G$ & 1.20 & 0.019 & 0.034 & 0.070 & 2.259 & $<0.008$ & 0.339 & 0.108 & 0.171 & 0.010 & 0.041 \\
\hline $30 \mathrm{G}$ & 0.07 & $<0.001$ & $<0.006$ & $<0.0006$ & 1.151 & $<0.008$ & 1.243 & 0.189 & $<0.001$ & 0.015 & 0.080 \\
\hline $31 \mathrm{G}$ & 0.18 & 0.008 & 0.004 & 0.023 & 0.436 & $<0.008$ & 0.400 & 0.726 & 0.040 & $<0.002$ & 0.078 \\
\hline
\end{tabular}

\section{Water resources contamination indices}

\section{Nitrate pollution index}

The source of nitrate in the groundwater is classified to nonpoint sources such as intensive agricultural activities and point sources such as irrigation of land by sewage effluents [40]. The surface water samples in the Abu Zaabal area are classified according to NPI values as follows: $43 \%$ of the samples are cleaned (unpolluted), 14\% are light-polluted, $14 \%$ of the samples are moderately polluted and $28 \%$ are significant pollution. Where the groundwater samples are $33 \%$ of samples are clean (unpolluted), 63\% are samples are light polluted and $4 \%$ of the samples are moderate polluted table 6 . The distribution of the NPI values presented that the majority of the study area located under light-polluted zone may be due to the influence of agricultural activities (nitrification of synthetic fertilizers and soil organic nitrogen). Where is the moderate pollution is located close to Bilbeis drain reflected the influence of groundwater recharge from the drain (fig. 5).

\section{Heavy metal pollution index (HPI)}

The Heavy metal pollution index (HPI) for water resources in the study area was calculated based on the concentration of $\mathrm{Al}, \mathrm{Cu}, \mathrm{Cd}, \mathrm{Fe}$, $\mathrm{Pb}, \mathrm{Mn}, \mathrm{Mo}$ and $\mathrm{Ni}$ use the permissible limits according to WHO, 2011. HPI of surface water samples ranged between 31.8 and 993.2 reflected wide variation in the surface water resources in the study area (table 6). Ismailia canal samples (3S and 29 S) are classified as good samples according to HPI values. The Quaternary groundwater samples can be classified according to HPI values as: $8 \%$ of the quaternary groundwater samples are good, $4 \%$ are poor, $4 \%$ are very poor and $84 \%$ of the samples are unsuitable. The distribution map of HPI values (fig. 6) reflects the increasing of the HPI values in the majority of the study area may be due to wider sources of pollution.

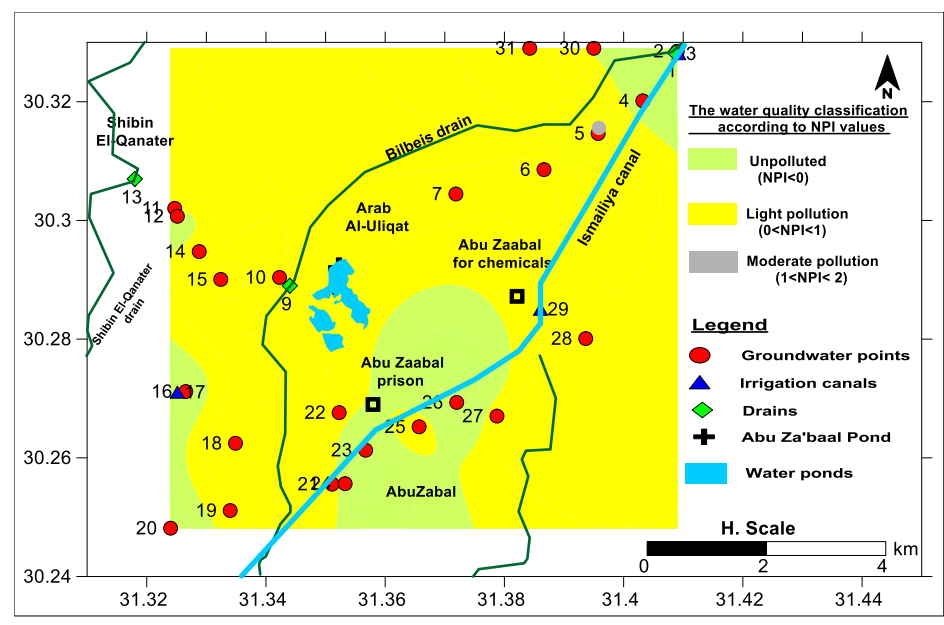

Fig. 5: Spatial distribution of the NPI values for the quaternary water samples in Abu Zaabal area 


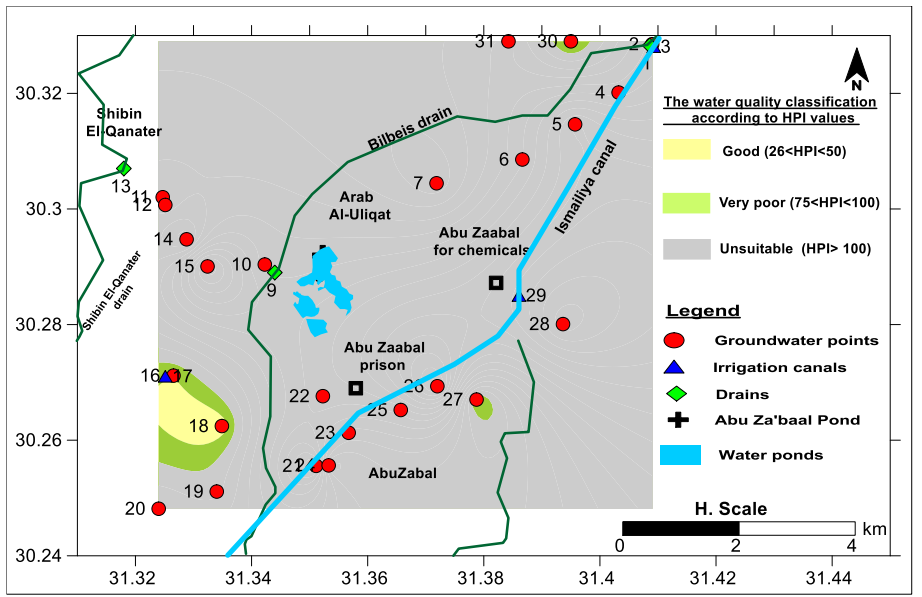

Fig. 6: Spatial distribution of the HPI values for the quaternary water samples in Abu Zaabal area

Table 6: The contamination indices, water quality indices for drinking and evaluation for water resources in the study area

\begin{tabular}{|c|c|c|c|c|c|c|c|}
\hline Sample & NPI & HPI & DWQI & SAR & $\% \mathrm{Na}$ & MR & RSC \\
\hline \multicolumn{8}{|c|}{ Surface water samples } \\
\hline $1 \mathrm{~S}$ & 2.75 & 993.2 & 82.6 & 3 & 58.5 & 72.4 & -3.2 \\
\hline $3 S$ & -0.5 & 40.7 & 16.4 & 0.7 & 35.8 & 51.6 & -0.5 \\
\hline $8 \mathrm{~S}$ & 2.5 & 1136.2 & 408.4 & 14.3 & 78.4 & 53.6 & -22.2 \\
\hline 9S & 1.9 & 655.3 & 76.1 & 2.9 & 62.9 & 62.9 & -3.2 \\
\hline $13 S$ & 0.4 & 644.3 & 45.4 & 2.2 & 57.9 & 53.6 & -2.5 \\
\hline $17 \mathrm{~S}$ & -0.3 & 366.6 & 20.9 & 0.7 & 35.4 & 50.2 & -1.5 \\
\hline $29 S$ & -0.6 & 31.8 & 16.2 & 0.8 & 35.7 & 89.2 & -0.6 \\
\hline \multicolumn{8}{|c|}{ Groundwater samples } \\
\hline $2 \mathrm{G}$ & -0.2 & 634.9 & 18.8 & 0.6 & 33.2 & 95.1 & -0.8 \\
\hline $4 G$ & -0.3 & 655.5 & 31.1 & 0.9 & 32.9 & 87.3 & -2.8 \\
\hline $5 G$ & 1.1 & 1127.2 & 211.1 & 5.4 & 59 & 32.3 & -19.2 \\
\hline $6 \mathrm{G}$ & 0.2 & 681.1 & 48.7 & 1.4 & 41.3 & 53.2 & -3.6 \\
\hline $7 \mathrm{G}$ & 0.25 & 218.4 & 91.2 & 2.9 & 53.8 & 77.8 & -7.5 \\
\hline $10 \mathrm{G}$ & 0.3 & 655.5 & 137.6 & 3 & 46.7 & 78.3 & -14 \\
\hline $11 \mathrm{G}$ & 0.25 & 559.3 & 63.5 & 1.8 & 44.6 & 27.1 & -5 \\
\hline $12 \mathrm{G}$ & -0.05 & 571.1 & 60.0 & 2.4 & 52.8 & 80.8 & -4.6 \\
\hline $14 \mathrm{G}$ & 0.2 & 220 & 58.2 & 2.7 & 59.2 & 44.1 & -2.9 \\
\hline $15 G$ & 0.5 & 1316.6 & 250.6 & 13.4 & 81.6 & 80.5 & -6.7 \\
\hline $16 \mathrm{G}$ & -0.05 & 97.8 & 128.2 & 9.4 & 81.2 & 36.5 & -2.3 \\
\hline $18 \mathrm{G}$ & 0.4 & 36.5 & 46.2 & 2.3 & 59.6 & 78.2 & -2.1 \\
\hline $19 G$ & 0.2 & 268.7 & 88.8 & 5.7 & 74.2 & 58.2 & 0.2 \\
\hline $20 \mathrm{G}$ & -0.1 & 417.1 & 49.4 & 2.8 & 60.6 & 74.2 & -1.8 \\
\hline $21 G$ & 0.35 & 1246.4 & 24.3 & 0.9 & 42 & 61 & -0.6 \\
\hline $22 \mathrm{G}$ & 0.15 & 853.5 & 107.7 & 3.2 & 54.3 & 36.2 & -7.8 \\
\hline $23 \mathrm{G}$ & -0.1 & 567.3 & 50.8 & 1.7 & 43.9 & 29.7 & -3.4 \\
\hline $24 G$ & -0.2 & 258.3 & 19.6 & 0.9 & 39.8 & 82 & -0.6 \\
\hline $25 G$ & 0.25 & 835.2 & 37.0 & 1.2 & 39.6 & 48.7 & -1.5 \\
\hline $26 G$ & -0.4 & 1583.7 & 31.6 & 0.8 & 27.9 & 42.5 & -2.6 \\
\hline $27 \mathrm{G}$ & 0.25 & 64.3 & 43.3 & 1.2 & 40.2 & 73.2 & -3.5 \\
\hline $28 \mathrm{G}$ & 0.3 & 1574.4 & 99.2 & 1.7 & 37.2 & 17.5 & -12.4 \\
\hline $30 \mathrm{G}$ & 0.05 & 39.5 & 33.9 & 0.9 & 31.3 & 50.2 & -1.5 \\
\hline $31 \mathrm{G}$ & 0.6 & 525.7 & 38.3 & 1 & 29.6 & 94.5 & -1.9 \\
\hline
\end{tabular}

\section{Evaluation of groundwater for human drinking}

The comparison between the maximum permissible limits major, minor, trace and heavy metals for human drinking (table 7) with the concentrations of these constituents in groundwater and surface water of the investigated samples in the study area leads to the following conclusions:

a) Evaluation of water in human drinking suitability according to physical properties reflected that $100 \%$ of water samples (ground and surface) are suitable in respect to $\mathrm{pH}$. $66.7 \%$ of groundwater samples and $85.7 \%$ of surface water samples are suitable for human drinking in respect to TDS. $70.8 \%$ of groundwater samples and $85.7 \%$ of surface water samples are suitable for human drinking in respect to $\mathrm{TH}$. b) Evaluation of water for human drinking suitability according to major constituents reflected that $100 \%, 91.6 \%, 66.7 \%, 83.3 \%$ and $79.2 \%$ of groundwater samples are suitable for drinking purposes in respect to $\mathrm{Mg}, \mathrm{Ca}, \mathrm{SO}_{4}, \mathrm{Cl}$ and $\mathrm{Na}$, respectively. $100 \%$ and $85.7 \%$ of surface water samples are suitable for drinking purposes in respect $(\mathrm{Mg}, \mathrm{Ca})$ and $\left(\mathrm{SO}_{4}, \mathrm{Cl}, \mathrm{Na}\right)$, respectively.

c) Evaluation of water for human drinking suitability according to minor-trace constituents and heavy metals reflected that:

- $91.7 \%$ of groundwater samples and $57.1 \%$ of surface samples are suitable in respect to Mo.

- $87.5 \%$ of groundwater samples and $57.1 \%$ of surface samples are suitable in respect to $\mathrm{Ni}$. 
- $16.7 \%$ of groundwater samples and $28.6 \%$ of surface samples are suitable in respect to $C d$.

- $100 \%$ of water samples (ground and surface) are suitable in respect to $\mathrm{Cu}$ and $\mathrm{Zn}$.

- $87.5 \%, 91.7 \%, 100 \%, 16.7 \%$ and $66.7 \%$ of groundwater samples and $100 \%, 28.6 \%, 42.8 \%, 28.6 \%, 71.4 \%$ of surface water samples is suitable in respect to $\mathrm{Pb}, \mathrm{Al}, \mathrm{NO}_{3}$, $\mathrm{Fe}$ and $\mathrm{Mn}$, respectively.

- The evaluation of the water resources for drinking purposes according to quality parameters can be estimated water quality index values (WQI). The water quality index in this study is calculated according to 8 parameters (TDS, $\mathrm{HCO}_{3}, \mathrm{Cl}, \mathrm{SO}_{4}, \mathrm{NO}_{3}$, $\mathrm{Ca}$, $\mathrm{Mg}$, and $\mathrm{Na}$ ) has been assigned a weight (wi) according to its relative importance in the overall quality of water for drinking purposes table 3 [25]. The results of the drinking water quality index (DWQI) reflected that $57 \%$ of surface water samples are excellent, $28.5 \%$ are good and $14 . \%$ of samples tapping to Belbis drain are very poor for drinking purposes (table 6 and table 8). The evaluation of the groundwater samples is classified as: $50 \%$ of the groundwater samples are excellent, $29 \%$ are good, $13 \%$ are poor and $8 \%$ are very poor. The distribution of drinking water quality index values for the groundwater samples in Abu Zaabal (fig. 7) area reflected the effect of the Belbis drain on the groundwater quality.

Table 7: Water quality guidelines used in evaluation for human drinking water quality index

\begin{tabular}{|c|c|c|}
\hline Parameter & Egyptian1 maximum permissible limit in $\mathrm{mg} / \mathrm{l}(2007)$ [30] & WHO guidelines for human drinking 2003 [41] \\
\hline pH-value & $6.5-8.5$ & $6.5-9.5$ \\
\hline $\mathrm{Na}(\mathrm{mg} / \mathrm{l})$ & 200 & 200 \\
\hline $\mathrm{Mg}(\mathrm{mg} / \mathrm{l})$ & 150 & 150 \\
\hline $\mathrm{K}(\mathrm{mg} / \mathrm{l})$ & & 12 \\
\hline $\mathrm{Ca}(\mathrm{mg} / \mathrm{l})$ & 350 & 200 \\
\hline $\mathrm{Cl}(\mathrm{mg} / \mathrm{l})$ & 250 & 250 \\
\hline $\mathrm{SO}_{4}(\mathrm{mg} / \mathrm{l})$ & 250 & 250 \\
\hline $\mathrm{NO}_{3}(\mathrm{mg} / \mathrm{l})$ & 45 & 50 \\
\hline TDS (mg/l) & 1000 (at $120 \mathrm{C}$ ) & 1000 \\
\hline Hardness as $\mathrm{CaCO}_{3}(\mathrm{mg} / \mathrm{l})$ & 500 & 500 \\
\hline $\mathrm{Al}(\mathrm{mg} / \mathrm{l})$ & 0.2 & 0.2 \\
\hline $\mathrm{Fe}(\mathrm{mg} / \mathrm{l})$ & 0.3 & 0.3 \\
\hline $\mathrm{Mn}(\mathrm{mg} / \mathrm{l})$ & 0.4 & 0.4 \\
\hline $\mathrm{Cu}(\mathrm{mg} / \mathrm{l})$ & 2 & 2 \\
\hline $\mathrm{Zn}(\mathrm{mg} / \mathrm{l})$ & 3 & 3 \\
\hline $\mathrm{Pb}(\mathrm{mg} / \mathrm{l})$ & 0.01 & 0.01 \\
\hline $\mathrm{Cr}(\mathrm{mg} / \mathrm{l})$ & - & 0.05 \\
\hline $\mathrm{Cd}(\mathrm{mg} / \mathrm{l})$ & 0.005 & 0.003 \\
\hline $\mathrm{Ni}(\mathrm{mg} / \mathrm{l})$ & 0.02 & 0.02 \\
\hline $\mathrm{B}(\mathrm{mg} / \mathrm{l})$ & 0.5 & 0.5 \\
\hline
\end{tabular}

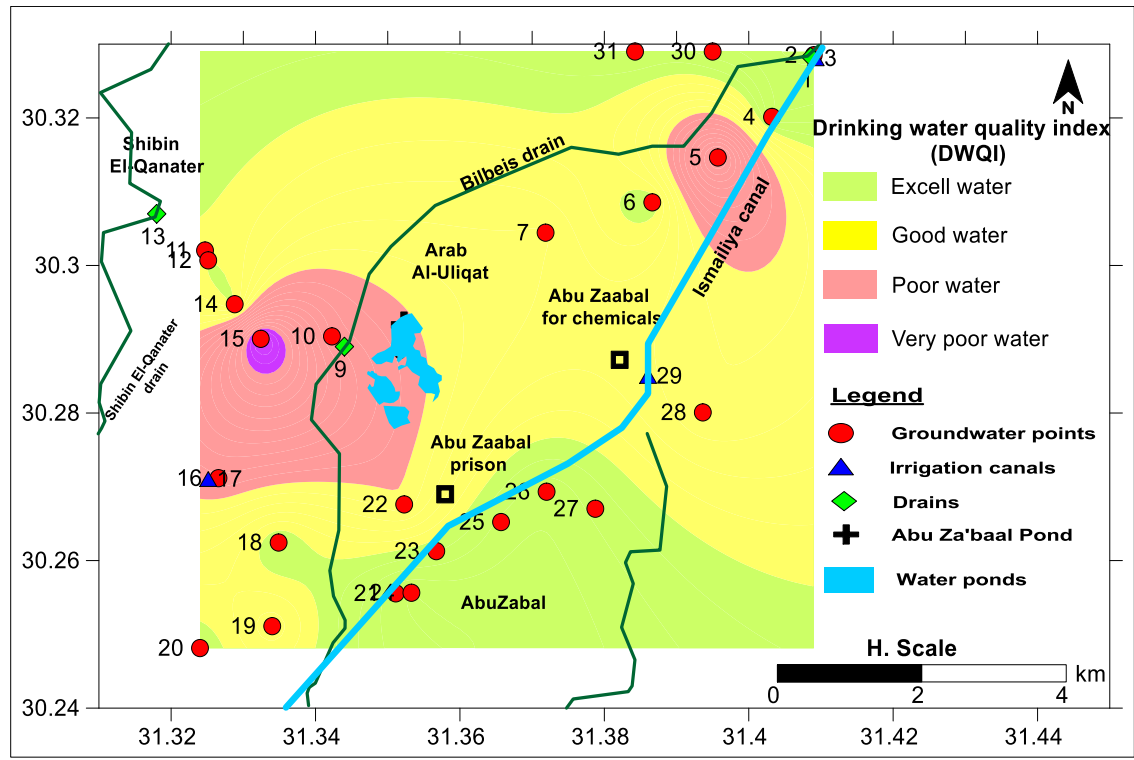

Fig. 7: Spatial distribution of the DWQI values for the quaternary water samples in Abu zaabal area

Table 8: Water quality index scale

\begin{tabular}{ll}
\hline Range & Type of water \\
\hline$<50$ & Excellent \\
$50-100$ & Good water \\
$100.1-200$ & Poor water \\
$200.1-300$ & Very poor water \\
$>300$ & Water unsuitable for drinking purposes \\
\hline
\end{tabular}

\section{The evaluation of water resources for irrigation purposes}

The suitability of water for irrigation is determined by its mineral constituents and the type of the plant and soil to be irrigated. Water quality used for irrigation is well recognized as an important factor in the productivity of crops. The suitability of water for irrigation is determined not only by the total amount of salt present but also by 
the kind of salt. Different chemical factors affecting the suitability of water for irrigation and its effect on crop production and soil quality. Among these are:

-Salinity hazard (EC)-total soluble salt content

-Sodium hazard (SAR)

-Sodium percentage ( $\mathrm{Na} \%$ ):
-Magnesium ratio (MR)

-Residual sodium carbonate (RSC)

\section{Salinity hazard (EC)}

Based on the EC, irrigation water can be classified into four categories [42] as shown in table 9.

Table 9: Classification of irrigation water based on salinity (EC) values

\begin{tabular}{|c|c|c|c|}
\hline Level & $\mathrm{EC}(\mu \mathrm{S} / \mathrm{cm})$ & Total dissolved salts (mg/l) & Hazard and limitations \\
\hline C1 & $<250$ & $<200$ & Low hazard; no detrimental effects on plants, and no soil buildup expected. \\
\hline $\mathrm{C} 2$ & $250-750$ & $200-500$ & Sensitive plants may show stress; moderate leaching prevents salt accumulation in soil. \\
\hline C3 & $750-2250$ & $500-1500$ & $\begin{array}{l}\text { Salinity will adversely affect most plants; requires selection of salt-tolerant plants, } \\
\text { careful irrigation, good drainage, and leaching. }\end{array}$ \\
\hline $\mathrm{C} 4$ & $>2250$ & $>1500$ & $\begin{array}{l}\text { Generally unacceptable for irrigation, except for very salt tolerant plants, excellent } \\
\text { drainage, frequent leaching, and intensive management. }\end{array}$ \\
\hline
\end{tabular}

Based on this classification, it should be noted that $20.8 \%$ of groundwater samples (samples Nos. 2 G, 4G, 21G, 24G and 26G) and $42.85 \%$ of surface water samples (samples Nos. 3S, 17S, and 29S) are classified as class C2. $62.5 \%$ of groundwater samples (Samples Nos. 6G, 7G, 11G, 12G, 14G, 18G, 19G, 20G, 22G, 23G, 25G, 27G, 28G, $30 \mathrm{G}$ and $31 \mathrm{G}$ ) and $42.85 \%$ of surface water samples (Samples Nos. $1 \mathrm{~S}, 9 \mathrm{~S}$ and 13S,) are classified as class C3 which are saline and then require selection of salt-tolerant plants, careful irrigation, good drainage, and leaching. $16.7 \%$ of groundwater samples (samples Nos. 5G, 10G, 15G and 16G) and $14.3 \%$ of surface water samples (Sample No. 8S) are classified as class C4.

\section{Sodium adsorption ratio (SAR)}

Continued use of water having a high SAR leads to a breakdown in the physical structure of the soil. The sodium replaces calcium and magnesium sorbed on clay minerals and causes dispersion of soil particles. This dispersion results in the breakdown of soil aggregates and causes cementation of the soil under drying conditions as well as preventing infiltration of rainwater. Classification of irrigation water based on SAR values is shown in table 10 .

Based on this classification, it should be noted that all samples are classified as class S1 except samples 8S and 15G are classified S2 table $6.20 .8 \%$ of groundwater samples (samples Nos.2G, 4G, 21G, $24 \mathrm{G}$ and $26 \mathrm{G}$ ) and $42.85 \%$ of surface water samples (samples Nos. $3 \mathrm{~S}, 17 \mathrm{~S}$, and $29 \mathrm{~S}$ ) in the study area lie in the fields C2-S1. $62.5 \%$ of groundwater samples (Samples Nos. 6G, 7G, 11G, 12G, 14G, 18G, 19G, 20G, 22G, 23G, 25G, 27G, 28G, 30G and 31G) and 42.85\% of surface water samples(Samples Nos. 1S, 9S and 13S,) lie in the fields C3-S1.16.7\% of groundwater samples (samples Nos. 5G, 10G and 16G) lie in the fields C4-S1. 4.2\% of groundwater samples (samples No. 15G) and $14.3 \%$ of surface water samples (Samples No. 8S) lie in the fields C4-S2, which reflect unacceptable for irrigation, except for very salt-tolerant plants, excellent drainage, frequent leaching, and intensive management and problems on fine texture soils and sodium-sensitive plants, especially under low-leaching conditions, but could be used on sandy soils with good permeability.

\section{Sodium percentage ( $\mathrm{Na} \%)$}

The groundwater samples are suitable for irrigation in 33.3\% of samples and $42.8 \%$ of surface water samples according to $\mathrm{Na} \%$ values. $50 \%$ and $28.6 \%$ from groundwater samples and surface water samples, respectively, were Permissible. $8.3 \%$ and $28.6 \%$ from groundwater samples and surface water samples, respectively, were doubtful. $8.3 \%$ and zero\% from groundwater samples and surface water samples, respectively, were unsuitable (table 11).

Table 10: Classification of irrigation water based on SAR values [42]

\begin{tabular}{|c|c|c|c|}
\hline Level & SAR & Quality & Hazard \\
\hline S1 & $<10$ & Low sodium & No harmful effects from sodium. \\
\hline S2 & $10-18$ & Medium sodium & $\begin{array}{l}\text { Problems on fine texture soils and sodium-sensitive plants, especially under low-leaching conditions, but } \\
\text { could be used on sandy soils with good permeability. }\end{array}$ \\
\hline S3 & $18-26$ & High sodium & $\begin{array}{l}\text { Harmful effects could be anticipated in most soils and amendments such as gypsum would be necessary to } \\
\text { exchange sodium ions. }\end{array}$ \\
\hline S4 & $>26$ & Very high sodium & Generally unsatisfactory for irrigation. \\
\hline
\end{tabular}

Table 11: Suitability for irrigation based on sodium percent

\begin{tabular}{lll}
\hline Na\% & Suitability for irrigation & No. of samples \\
\hline$<20$ & Excellent & - \\
$20-40$ & Good & $8 \mathrm{G}-3 \mathrm{~S}$ \\
$40-60$ & Permissible & $12 \mathrm{G}-2 \mathrm{~S}$ \\
$60-80$ & Doubtful & $2 \mathrm{G}-2 \mathrm{~S}$ \\
$>80$ & Unsuitable & $2 \mathrm{G}$ \\
\hline
\end{tabular}

\section{Magnesium ratio (MR)}

Calcium and magnesium maintain equilibrium in most waters, in equilibrium. $\mathrm{Mg}^{2+}$ in the waters will adversely affect crop yield; magnesium impact on irrigated water is expressed as magnesium ratio (MR) (MR $>50 \%$ is suitable for irrigation and $M R<50 \%$ is unsuitable).

M. $R$ values reflected that $45.8 \%$ of investigating groundwater samples are unsuitable for irrigation table 6.

\section{Residual sodium carbonate (RSC)}

An excess of sodium bicarbonate and carbonate is considered to be detrimental to the physical properties of soils as it causes dissolution of organic matter in the soil, which in turn leaves a black stain on the soil surface on drying; this excess amount is denoted by Residual Sodium Carbonate (RSC).

All samples (ground and surface) is good for irrigation table 6. (R. S. $\mathrm{C}>2.5 \mathrm{meq} / \mathrm{l}$ is unsuitable for irrigation, RSC values from 1.25 to 2.5 
meq/l are doubtful and R. S. C $<1.25$ meq/l are good for irrigation) [43].

\section{CONCLUSION}

The water resources in the study area are generally alkaline in nature. $83.3 \%$ of groundwater samples are fresh water and $16.7 \%$ are brackish water. $85.7 \%$ of surface water samples are fresh and $14.3 \%$ is saline. The groundwater distribution of sulfate indicates the presence of local zones of high concentrations at Abu Zaabal, reflecting the effect of the saline pond from the west and the influence of the sulfate fertilizers in the new reclaimed land in the east. The NPI values presented that the majority of the study area located under light polluted zone due to the influence of agricultural activities (nitrification of synthetic fertilizers and soil organic nitrogen) and moderate pollution zone is located closed to Bilbeis drain reflected that the influence of groundwater recharge from the drain According to WQI values, the distribution of drinking water quality index values for the groundwater samples in Abu Zaabal area reflected the effect of the Belbis drain on the groundwater quality. $33.3 \%$ of groundwater and $42.8 \%$ of surface water samples are suitable for irrigation according to $\mathrm{Na} \%$ values. $45.8 \%$ of investigated groundwater samples are unsuitable for irrigation according to $\mathrm{M}$. $\mathrm{R}$ values.

\section{FUNDING}

Nil

\section{AUTHORS CONTRIBUTIONS}

Prof. Dr. Ragaa El-Sheikh; Prof. Dr. Ayman A. Gouda and Dr. Ehab Zaghlool have been generated the research idea and interpreted the data and helped to draft the manuscript. Dr. Mohamed E. A. Ali has suggested the research idea and participated in the design of the study. Mr. Ibrahim Hegazy was prepared the solutions, carried out the experiments, interpreted the data and helped to draft the manuscript.

\section{CONFLICTS OF INTERESTS}

The authors confirm that this article's content has no conflict of interest.

\section{REFERENCES}

1. Al-Shamaa IM, Ali BM. Hyrological relationship between surface and groundwater in badra-jassan basin. Iraqi J Sci. 2012;2:335-40.

2. Drain B, El-Baqar Drain B. System/Egypt environmental studies on water. Quality; 2009.

3. Geriesh MH, Balke KD, El-Rayes AE. Problems of drinking water treatment along Ismailia Canal Province, Egypt. J Zhejiang Univ Sci B. 2008;9(3):232-42. doi: 10.1631/jzus.B0710634, PMID 18357626.

4. Khalil MK, Radwan A, El-Moselhy KM. Distribution of phosphorus fractions and some of the heavy metals in surface sediments of Burullus lagoon and the adjacent Mediterranean Sea. Egypt J Aquat Res. 2007;33:277-89.

5. Abbas M, Shakweer L. Effect of ecological and biological factors on the uptake and concentration of trace elements by aquatic organisms at Edku Lake. Egypt J Aquat Res. 2005;31:271-87.

6. Gupta NV, Hm N, G R. Validation of the water purification system. Asian J Pharm Clin Res. 2017;10(4):409-16. doi: 10.22159/ajpcr.2017.v10i4.16955.

7. Rashid I, Romshoo SA. Impact of anthropogenic activities on water quality of Lidder River in Kashmir Himalayas. Environ Monit Assess. 2013;185(6):4705-19. doi: 10.1007/s10661012-2898-0, PMID 23001554.

8. Korany E, Abdel Aal M. Groundwater response in the urban sectors of Cairo environs, Egypt. In: Hydrological processes and water management in urban areas. International Symposium; 1988. p. 429-36.

9. El-Fakharany MA, Mansour NM, Yehia MM, Monem M. Evaluation of groundwater quality of the Quaternary aquifer through multivariate statistical techniques at the southeastern part of the Nile Delta, Egypt. Sustain Water Resour Manag. 2017;3(1):71-81. doi: 10.1007/s40899-017-0087-6.
10. Korany B, Brynen R, Noble P. The analysis of national security in the Arab context: restating state of the art. In: The many faces of national security in the Arab world Palgrave. London: Macmillan; 1993. p. 1-23.

11. Taha AA, Serag El-Din H, El-Hadad M. Hydrogeological situation of the area between ismailia canal and caro-ismailia desert road. J Environ Sci. 1997;14:147-79.

12. Pawlikowski M, Pająk L, Mazurek J, Eweida A, Mahmoud K. Wody geotermalne Zatoki Suezkiej (Egipt) i możliwości ich praktycznego wykorzystania. Gospod Surowcami Min. 1999;15:89-97.

13. Yehia MM. Environmental impacts of sewage irrigation water on groundwater quality of northeast Cairo, Egypt. Eur Res J. 2000;72:176-93.

14. El Fakharany MA, Mansour NM. Assessment of water resources quality at the southeastern part of the Nile Delta, Egypt. ICWCAR; 2009. p. 12-4.

15. Onken A, Sunderman HD. Colorimetric determinations of exchangeable ammonium, urea, nitrate, and nitrite in a single soil extract1,2. Agron J 1977;69(1):49-53. doi: 10.2134/agronj1977.00021962006900010013x.

16. Fishman MJ, Friedman LC, Chapter A. Methods for determination of inorganic substances in water and fluvial sediments. US Geol Surv. In: Open-file report, Denver, CO, USA. Bk. 5; 1985. p. 485-98.

17. Brar MS, Malhi SS, Singh AP, Arora CL, Gill KS. Sewage water irrigation effects on some potentially toxic trace elements in soil and potato plants in northwestern India. Can J Soil Sci. 2000;80(3):465-71. doi: 10.4141/S99-106.

18. APHA (American Public Health Association). Standard methods for the examination of water and wastewater. 21st ed. Washington, DC: American Public Health Association; 2005.

19. Appelo A, Postma D. Geochemistry, groundwater and pollution. 2nd ed. Balkama, Rotterdam; 2005.

20. Ragunath HM. Groundwater. New Delhi: Wiley Eastern Ltd; 1987. p. 563-69.

21. Horton RK. An index number system for rating water quality. J (Water Pollut Control Fed). 1965;37:300-6.

22. Mohan S, Nithila P, Reddy S. Estimation of heavy metal in drinking water and development of heavy metal pollution index. J Environ Sci Health. 1996;31:283-9.

23. Spalding RF, Exner ME. Occurrence of nitrate in groundwater- a review. J Environ Qual. 1993;22(3):392-402. doi: 10.2134/jeq1993.00472425002200030002x.

24. Kumar GVSRP, Sanand VS, Kumar NS, Murthy BS. Assessment of water quality of Thatipudi reservoir of vizianagaram distrinct of Andhra Pradesh. Innovare J Sci. 2013;1:20-4.

25. Doneen LD. Notes on water quality in agriculture. Water science and engineering. Department of Water Sciences and Engineering, University of California; 1964. p. 4001.

26. Ayers RS, Westcot DW. Water quality for agriculture. Rome: food and agriculture organization of United Nations; 1985. p. 174.

27. Khodapanah L, Sulaiman WNA, Khodapanah N. Groundwater quality assessment for different purposes in Eshteharddistrict, Tehran, Iran. Eur J Sci Res. 2009;36:543-53.

28. Paliwal KV. Irrigation with saline water. ICARI Monograph No. 2 (New Series). New Delhi; 1972. p. 198.

29. Egyptian Higher Committee for Water. Water quality guidelines for human drinking, domestic and laundry uses. Egypt; 2007.

30. World Health Organization (WHO). Guidelines for drinking water quality, 4thed. Geneva; 2011. p. 924-78.

31. El-Sayed MH, El-Aassar AM, El-Fadl MA, El-Gawad AM. Hydrogeochemistry and pollution problems in 10th of Ramadan City, East El-Delta, Egypt. JASR. 2012;4:1959-72.

32. Taha A, El-Mahmoudi A, El-Haddad I. Pollution sources and related environmental impacts in the new communities southeast Nile Delta, Egypt. EJER. 2004; 9:35-49.

33. Goher ME, Hassan AM, Abdel-Moniem IA, Fahmy AH, El-sayed SM. Evaluation of surface water quality and heavy metal indices of Ismailia Canal, Nile River, Egypt. Egypt J Aquat Res. 2014;40(3):225-33. doi: 10.1016/j.ejar.2014.09.001.

34. Nikanorov AM, Brazhnikova LV. Types and properties of water II: Water chemical composition of rivers. Lakes Wetlands. 2009;2:42-80. 
35. Islam MJ, Hossain AM, Rahman MS, Khandoker MH, Zahan MN. Hydrogeochemistry and usability of groundwater at the Tista river basin in Northern Bangladesh. IJST. 2019;12(47):1-12. doi: $10.17485 / \mathrm{ijst} / 2019 / \mathrm{v} 12 \mathrm{i} 47 / 147961$.

36. El-Rawy M, Ismail E, Abdalla O. Assessment of groundwater quality using GIS, hydrogeochemistry, and statistical factor analysis in Qena governorate, Egypt. Desalin Water Treat. 2019:162:14-29. doi: 10.5004/dwt.2019.24423.

37. Lewis WM, Morris DP. Toxicity of Nitrite to Fish: A Review. Trans Am Fish Soc. 1986;115(2):183-95. doi: 10.1577/15488659(1986) 115<183:TONTF>2.0.C0;2.

38. Ramesh K, Jagadeeswari BP. Hydrochemical characteristics of groundwater for domestic and irrigation purposes in Periyakulam taluk of Theni district, Tamil nadu. Int Res J Environ Sci. 2012;1:19-27.
39. McLay CDA, Dragten R, Sparling G, Selvarajah N. Predicting groundwater nitrate concentrations in a region of mixed agricultural land use: a comparison of three approaches. Environ Pollut. 2001;115(2):191-204. doi: 10.1016/s02697491(01)00111-7, PMID 11706792.

40. World Health Organization (WHO). WHO guidelines for drinking-water Quality. Chromium in Drinking-Water; 2003.

41. College of Agriculture sciences. Irrigation water quality. Pennsylvania State Univ. Ersity USA; 2002.

42. El Behairy RA, El Baroudy AA, Ibrahim MM, Shokr MS. Assessment and mapping of surface water quality index for irrigation purpose: case study northwest of Nile Delta, Egypt. Menoufia J Soil Sci. 2021;6(5):163-82. doi: 10.21608/ mjss.2021.182346. 